DIFUSI

Volume1, No. 2, Juli 2018

\title{
PEMBERDAYAAN MASYARAKAT DESA DALAM MENINGKATKAN MUTU PELAYANAN MASYARAKAT MELALUI APLIKASI PELAYANAN TERPADU DI DESA SUKA MULIA KECAMATAN SUNGAI MELAYU RAYAK KABUPATEN KETAPANG KALIMANTAN BARAT
}

\author{
Eka Wahyudi ${ }^{1)}$, Indra Pratiwi ${ }^{2)}$ \\ 1,2 Jurusan Teknik Informatika Politeknik Negeri Ketapang \\ e-mail: ${ }^{1)}$ ekawahyudi_algebra@ymail.com, ${ }^{2)}$ indrapratiwirahman@gmail.com
}

\begin{abstract}
Abstrak
Aparatur Desa Suka Mulia yang kegiatannya tidak terlepas dengan kegiatan surat menyurat sebagai sarana komunikasi dengan pihak internal dan eksternal organisasi/lembagal perusahaan/individu membutuhkan peningkatan dalam pelayanan masyarakat maupun sistem manajemen surat, pengelolaan data dalam sistem surat-menyurat yang dilakukan secara tepat, cepat, dan akurat sehingga proses pelayanan terhadap masyarakat bisa lebih efektif dan efisien. Selama ini aparatur desa masih menggunakan sistem manual pada proses pembuatan dan pengarsipan surat menyurat sehingga pengelolaan menjadi kurang efisien. Tujuan dari kegiatan pemberdayaan masyarakat ini adalah memberikan solusi alternatif dalam menghadapi kendala yang ada tersebut dengan memberikan pelatihan, peningkatan pengetahuan dan ketrampilan serta pendampingan kepada perangkat desa dalam menerapkan cara penggunaan aplikasi dan memanfaatkan komputer dalam mempermudah pelayanan publik sehingga pelayanan publik terhadap masyarakat di desa Suka Mulia akan lebih baik, cepat dan tepat. Metoda pendekatan dalam menyelesaikan masalah yang ada yaitu dengan melakukan Metode Transfer Teknologi (Ipteks) melalui pelatihan, praktek, dan pendampingan tentang penggunaan Aplikasi Pelayanan Terpadu sesuai standar dan mengenalkan pada mitra tentang Aplikasi Pelayanan Terpadu yang lebih baik, efisien, dan cepat sehingga proses pelayanan terhadap masyarakat bisa lebih efektif dan efisien. Pelaksanaan kegiatan pemberdayaan masyarakat terbagi menjadi tiga tahap, yaitu persiapan, pelaksanaan/pelatihan, dan monitoring. Hasil kegiatan pemberdayaan masyarakat dapat diukur dari kemampuan dan keberhasilan masyarakat dalam menerima, memahami, dan menerapkan Aplikasi Pelayanan Terpadu secara konsisten dan kontinu, serta proses pelayanan kepada masyarakat menggunakan Aplikasi Pelayanan Terpadu lebih mudah, cepat dan akurat.
\end{abstract}

Kata kunci : Pemberdayaan, Masyarakat Desa, Pelayanan Terpadu, Aplikasi.

\section{PENDAHULUAN}

Pelayanan Masyarakat Terpadu yang berkualitas menjadi salah satu ciri dari tata pemerintahan yang baik. Kinerja Pelayanan Masyarakat Terpadu sangat besar pengaruhnya terhadap kualitas kehidupan masyarakat. Masih banyak desa yang memberikan pelayanan terhadap masyarakatnya dengan cara yang manual. Salah satunya di Desa Suka Mulia dalam pelayanan terhadap keperluan suratmenyurat sering kali memakan waktu yang lama.
Berdasarkan analisis situasi dan wawancara terhadap masyarakat, kepala dusun, kepala urusan pemerintahan dan kepala desa Suka Mulia kecamatan Sungai Melayu Rayak serta observasi awal terhadap beberapa masyarakat dan perangkat desa yaitu kaur pemerintahan dan kaur TU dan umum di desa Suka Mulia dapat dirumuskan beberapa masalah yang menjadi kendala utama dalam pengembangan teknologi informasi di desa adalah:

1. Lamanya waktu dalam pengurusan surat menyurat. 
2. Sarana dan prasarana yang belum menunjang, dalam hal ini pembuatan/pengurusan surat menyurat masih menggunakan sistem manual.

3. Kurangnya pemanfaatan komputer dalam mempermudah pelayanan publik, sehingga proses pengolahan data surat menyurat memakan waktu yang lama, kurang tepat dan kurang akurat.

Perubahan akan terjadi jika Aplikasi terkait Pelayanan Masyarakat Terpadu lingkup kerja Desa Suka Mulia sudah diterapkan. Perubahan tersebut lebih mendominasi pada pelayanan surat-menyurat yang tidak perlu lagi menginputkan data kependudukan dikarenakan data warga desa tersebut sudah tersimpan di database sebuah sistem yang akan diterapkan. Tidak hanya itu, sistem ini menyediakan fasilitas print data suratmenyurat seperti surat pengantar dan surat keterangan serta pemanfaatan E-KTP yang dimiliki warga desa sebagai kartu identifikasi data kependudukan.

Oleh karena itu, perlu adanya sistem informasi untuk mengatasi permasalahan di atas. Melalui kegiatan pemberdayaan masyarakat ini pengabdi membangun sebuah sistem berbasis desktop. Sistem ini dibangun dengan tujuan menciptakan perubahan baru terkait Pelayanan Masyarakat Terpadu di Desa Suka Mulia dengan memanfaatkan fasilitas komputer yang ada dalam penerapan sistem. Selain itu, dalam kegiatan pemberdayaan masyarakat pengabdi meningkatkan pengetahuan dan ketrampilan perangkat desa dalam menerapakan cara penggunaan aplikasi dan memanfaatkan komputer dalam mempermudah pelayanan publik melalui pelatihan dan workshop. Dengan adanya sistem ini diharapkan dapat meningkatkan efektivitas dan efisiensi dalam Pelayanan Masyarakat Terpadu di Desa Suka Mulia. Sistem ini dibangun untuk menjadi alternatif sebagai pelengkap maupun pengganti dari sistem manual.

\section{Solusi}

Solusi yang dilakukan dalam kegiatan pemberdayaan masyarakat ini meliputi beberapa rangkaian kegiatan yaitu:
1. Sosialisasi Aplikasi Pelayanan Terpadu dan kelebihan penggunaan aplikasi ini kepada mitra binaan.

2. Memberikan pelatihan atau workshop tentang penggunaan Aplikasi Pelayanan Terpadu dan pelatihan tentang memanfaatkan komputer dalam mempermudah pelayanan publik, mengolahan data surat menyurat tanpa memakan waktu yang lama, tepat dan akurat, sehingga dengan bantuan teknologi informasi/aplikasi ini diharapakan proses pengolahan data surat menyurat dapat dilakukan lebih efektif dan efisien.

3. Mempersiapkan peralatan dan sarana penunjang lainnya selain peralatan yang dimiliki oleh mitra binaan.

4. Memberikan praktek kepada mitra tentang penggunaan Aplikasi Pelayanan Terpadu.

5. Melakukan monitoring dan evaluasi pada mitra binaan terkait dengan perubahan atau hasil yang diperoleh setelah program ini dilaksanakan.

\section{Tujuan Kegiatan Pemberdayaan Masyarakat}

Kegiatan Program Kemitraan Masyarakat yang ditujukan kepada Masyarakat dan Perangkat di desa Suka Mulia, bertujuan sebagai berikut:

1. Meningkatkan mutu pelayanan publik di desa Suka Mulia.

2. Efektivitas pelayanan publik terhadap masyarakat di desa Suka Mulia akan lebih lebih baik, cepat dan tepat.

3. Meningkatkan pengetahuan dan ketrampilan kepada perangkat desa dalam menerapakan cara penggunaan aplikasi dan memanfaatkan komputer dalam mempermudah pelayanan publik.

\section{Dampak/Manfaat Kegiatan \\ Pemberdayaan Masyarakat}

Manfaat Kegiatan Program Kemitraan Masyarakat ini adalah sebagai berikut :

1. Peningkatan mutu pelayanan publik, efektivitas pelayanan publik terhadap masyarakat di desa Suka Mulia akan lebih lebih baik, cepat dan tepat. 
2. Peningkatan pengetahuan dan ketrampilan kepada perangkat desa dalam menerapkan cara penggunaan aplikasi dan memanfaatkan komputer dalam mempermudah pelayanan publik.

3. Pemanfaatan E-KTP dalam Penggunaan Aplikasi Pelayanan Masyarakat Terpadu di Desa Suka Mulia secara maksimal.

\section{METODE}

Kegiatan Pengabdian Masyarakat di Desa Suka Mulia adalah berangkat dari pendekatan hasil analisis situasi yang dijumpai dan disepakati oleh Mitra. Metode yang digunakan dalam pengabdian ini adalah metode pendekatan yang terdiri dari tiga tahapan yaitu penyadaran, pengkapasitasan dan pemberdayaan/ pelembagaan. Metode penyadaran adalah transfer Ipteks yang diimplementasikan dalam bentuk pelatihan dan pendampingan. Pelatihan dimulai dengan ceramah untuk menggugah kesadaran dan memberi pengetahuan, dilanjutkan dengan demonstrasi untuk memberi pengetahuan praktis. Metode pengkapasitasan adalah menerapkan ilmu pengetahuan dan teknologi melalui pelatihan (workshop) untuk melatih keterampilan sehingga terjadi pengkapasitasan Ipteks masyarakat. Metode pemberdayaan/pelembagaan adalah pendampingan untuk memberdayakan sehingga penguasaan pengetahuan dan keterampilan Iptek dapat diimplementasikan untuk menjadikan keberdayaan dari masyarakat dalam memecahkan persoalannya. Adapun secara rinci tahapan tersebut dipaparkan sebagai berikut:

A. Tahap Persiapan

Pada tahap ini ada beberapa kegiatan yang dilakukan, yaitu:

1. Observasi

Observasi merupakan tahap pertama yang dilakukan dalam pengabdian ini yakni melakukan peninjauan ke Desa Suka Mulia. Dari peninjauan tersebut, ditemukan permasalahan terkait pelayanan masyarakat yang berhubungan dengan pembuatan surat menyurat yang selama ini penginputan data kependudukan dalam melengkapi isi surat masih manual. Pada kegitan ini meliputi perumusan masalah, pengumpulan data dan analisis data.

2. Studi Pendahuluan

Pada tahap ini tim Kegiatan Pemberdayaan Masyarakat mencari informasi dari berbagai sumber ilmilah seperti buku, jurnal dan lain sebagainya. Sehingga, ada beberapa manfaat yang diharapkan untuk didapatkan dalam melakukan tahapan ini yaitu mengetahui dengan pasti masalah yang akan diteliti, mengetahui di mana dan kepada siapa informasi dapat diperoleh, mengetahui teknik apa yang akan tepat untuk memperoleh data, dapat menentukan cara yang tepat untuk menganalisis data, mengetahui sistem basis apa yang tepat untuk diterapkan, serta tahu bagaimana harus mengambil kesimpulan dan memanfaatkan hasil.

3. Koordinasi dengan Mitra

Hasil justifikasi permasalahan telah disepakati oleh mitra dan perumusan serta penentuan tujuan kegiatan pengabdian dapat dibuat. Dari hal tersebut muncul bentuk-bentuk solusi yang ditawarkan oleh tim P3KM Jurusan Teknik Informatika yaitu sosialisasi dan pelatihan, monitoring serta evaluasi kegiatan. Bentuk-bentuk solusi yang ditawarkan tersebut, tentunya memerlukan koordinasi dengan mitra agar tujuan kegiatan pemberdayaan maysarakat tercapai.

B. Kegiatan Sosialisasi dan Pelatihan Kegiatan pada tahap ini dalam bentuk sosialisasi dan pelatihan. Tim P3KM teknik Informatika memberikan sosialisasi dan pelatihan mengenai penggunaan teknologi informasi aplikasi pelayanan terpadu dalam pelayanan terhadap masyarakat.

C. Kegiatan Monitoring dan Evaluasi

Tahap monitoring dari hasil kegiatan pelatihan yang telah dilakukan, dimana indikator keberhasilan kerja dapat dilihat dari sejauh mana masyarakat telah memahami dan mempraktekkan penggunaan aplikasi pelayanan terpadu, melalui interview kepada perangkat desa terkait pelatihan dan implementasi penggunaan aplikasi pelayan terpadu 
dalam pelayanan terhadap masyarakat.

Selain itu akan dilakukan evaluasi terhadap aplikasi secara menyeluruh, apakah aplikasi tersebut dapat di implementasikan sesuai dengan kebutuhan masyarakat. Sehingga aplikasi yang dikembangkan dapat digunakan dengan mudah oleh masyarakat. Kemudian pada akhirnya tim P3KM teknik Informatika akan memberikan rekomendasi kepada pihak desa terkait upaya-upaya penerapan aplikasi pelayanan terpadu.

\section{Populasi}

Populasi dalam kegiatan pemberdayaan masyarakat ini adalah seluruh masyarakat Desa di Kecamatan Sungai Melayu Rayak. Daftar desa dapat dilihat pada Tabel 1.

Tabel 1. Daftar Desa di Kec. Sungai Melayu Rayak

\begin{tabular}{|l|l|}
\hline No & \multicolumn{1}{|c|}{ Nama Desa } \\
\hline 1 & Beringin Jaya \\
\hline 2 & Jairan Jaya \\
\hline 3 & Karya Mukti \\
\hline 4 & Kepuluk \\
\hline 5 & Piansak \\
\hline 6 & Sungai Melayu \\
\hline 7 & Sungai Melayu Baru \\
\hline 8 & Sungai Melayu Jaya \\
\hline 9 & Suka Mulia \\
\hline
\end{tabular}

\section{Sampel}

Sampel dari kegiatan pengabdian ini adalah Desa Suka Mulia sebagai tempat kegiatan pemberdayaan masyarakat. Aplikasi pelayanan masyarakat terpadu akan diimplementasikan di Desa Suka Mulia.

\section{Prosedur Pengumpulan Data}

Dalam pengabdian ini proses pengambilan dan pengumpulan data diperoleh setelah sebelumnya mendapatkan izin dari Kepala Desa Suka Mulia untuk mengadakan pengabdian. Sebagai langkah awal kegiatan, tim Kegiatan Pemberdayaan Masyarakat melaksanakan wawancara kepada perangkat desa terkait kebutuhan yang diperlukan hingga kendala yang dihadapi dalam menjalankan tugas sebagai perangkat desa. Setelah sesi wawancara selesai, tim Kegiatan Pemberdayaan Masyarakat dapat menentukan aplikasi berbasis apa yang cocok serta data yang dibutuhkan dalam pembangunan aplikasi. Kemudian, tim Kegiatan Pemberdayaan Masyarakat meminta data kependudukan dan format surat yang dibutuhkan untuk dapat diterapkan di aplikasi yang akan dibangun, sehingga data maupun format yang ada di aplikasi dapat disesuaikan seperti aslinya.

\section{Arsitektur Sistem}

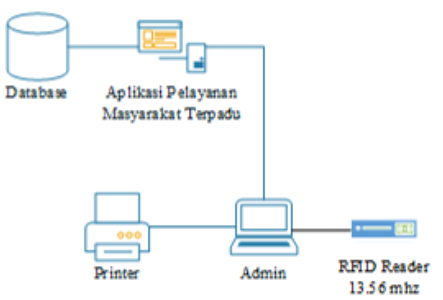

Gambar 1. Arsitektur Sistem

Gambar 1 merupakan arsitektur sistem yang terdiri dari Admin sebagai pengakses sistem, Printer dan RFID Reader sebagai alat pendukung sistem. Aplikasi Pelayanan Masyarakat Terpadu merupakan sebuah sistem yang digunakan Admin, serta Database sebagai penyimpanan data dari sistem.

\section{Perancangan Arus Data}

Berikut Perancangan Arus Data dengan menggunakan Data Flow Diagram (DFD) yang digambarkan dalam bentuk diagram konteks, diagram jenjang proses, DFD level 1, DFD level 2 proses 2, dan DFD Level 2 Proses 3:

\section{Diagram Konteks}

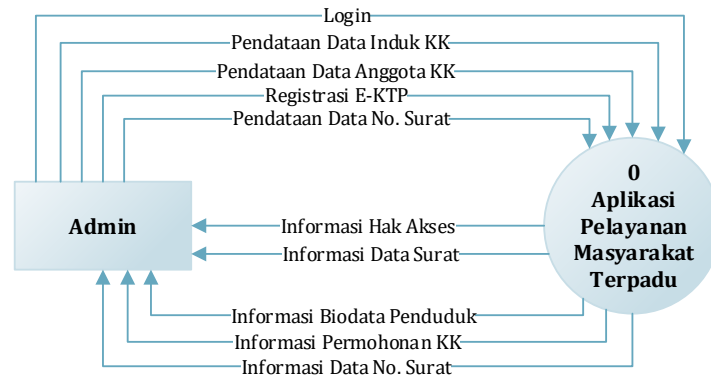

Gambar 2. Diagram Konteks

Gambar 2 merupakan Diagram Konteks yang terdiri dari 1 entitas yaitu Admin yang memiliki hak akses penuh terhadap sistem. Adapun proses yang dapat dilakukan admin 
terhadap sistem yaitu Login, Pendataan Data Induk KK, Pendataan Data Anggota KK, Registrasi E-KTP, dan Pendataan Data No. Surat. Serta Proses yang dihasilkan sistem yaitu: Informasi Hak Akses, Informasi Data Surat, Informasi Biodata Penduduk, Informasi Permohonan KK, Informasi Data No. Surat.

2. Diagram Jenjang Proses

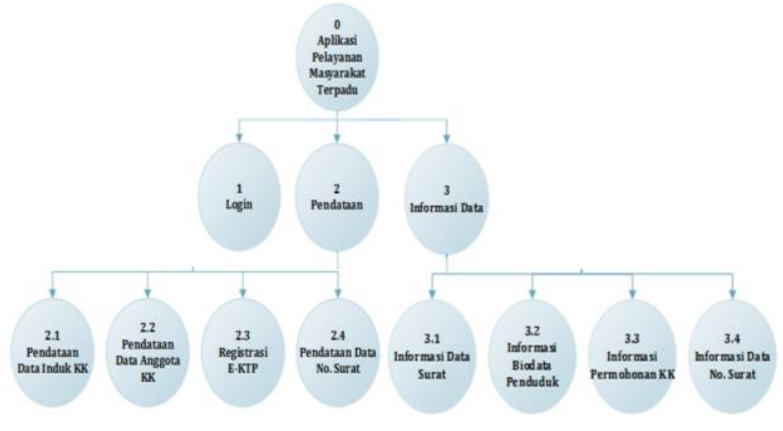

Gambar 3. Diagram Jenjang Proses

Gambar 3 merupakan Diagram Jenjang Proses yang menggambarkan tingkatan proses sistem sebagai dasar pembentukan DFD. Pada diagram jenjang proses ini terdapat 3 buah proses utama pembentuk DFD Level 1 yaitu, Login, Pendataan, dan Informasi Data.

Pada proses pendataan terbentuk DFD Level 2 Proses 2 yaitu, Pendataan Data Induk KK, Pendataan Data Anggota KK, Registrasi EKTP, dan Pendataan Data No. Surat.

Pada tingkatan proses informasi data akan membentuk DFD Level 2 Proses 3 yaitu, Informasi Data Surat, Informasi Biodata Penduduk, Informasi Permohonan KK, dan Informasi data No. Surat.

Pada Informasi Data Surat terdapat jenisjenis surat yaitu, Surat Pengantar (SP) dan Surat Keterangan (SK). Surat Pengantar (SP) terdiri dari SP Akta, SP Izin Keramaian, SP KK, dan SP SKCK. Sedangkan Surat Keterangan (SK) terdiri dari SK Ahli Waris, SK Beda Nama, SK Domisili, SK Hubungan Keluarga,
SK Kehilangan, SK Kelahiran, SK Kematian, SK Nikah, SK Tidak Mampu, SK Usaha.

\section{DFD Level 1}

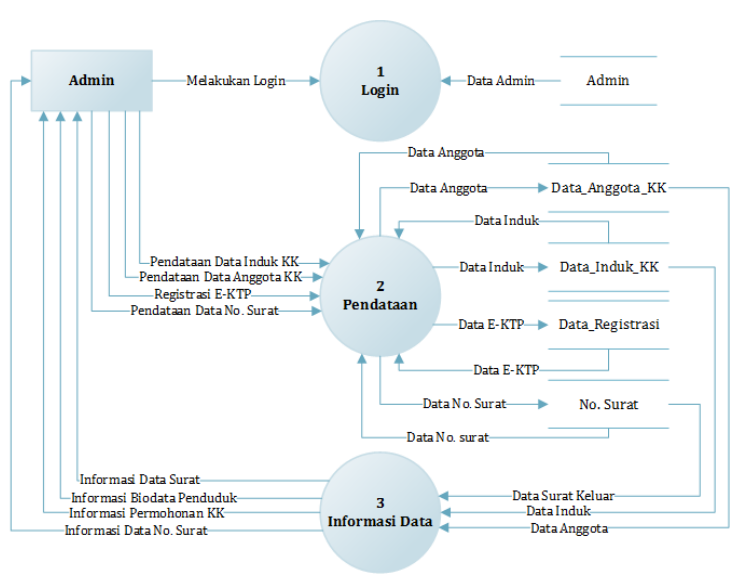

Gambar 4. DFD Level 1

Gambar 4 merupakan DFD Level 1 yang menjelaskan alur proses sistem. Pada DFD Level 1 terdapat 1 entitas yaitu Admin sebagai pengguna sistem. Serta, terdapat 3 buah proses yaitu Login, Pendataan, dan Informasi Data. Tahap pertama, Admin melakukan Login untuk masuk ke sistem dengan menginputkan username dan password yang teregistrasi pada sistem.

Tahap kedua, jika admin hendak melakukan pendataan terkait data induk KK, data anggota $\mathrm{KK}$, registrasi e-KTP, dan data no surat maka admin harus melakukan pendataan tersebut ke dalam 4 buah form. Form tersebut telah disediakan oleh sistem. Tahap ketiga, jika admin membutuhkan informasi atau data-data dari pendataan untuk ditampilkan ke dalam form surat, form biodata penduduk, form permohonan $\mathrm{KK}$, dan form nomor surat maka admin perlu mengginputkan NIK atau nomor KK sebagai data rujukan ke masing-masing form. Form tersebut telah disediakan oleh sistem dan bisa memanfaatkan e-KTP apabila telah melakukan registrasi ke dalam form registrasi e-KTP. 


\section{DFD Level 2 Proses Pendataan}

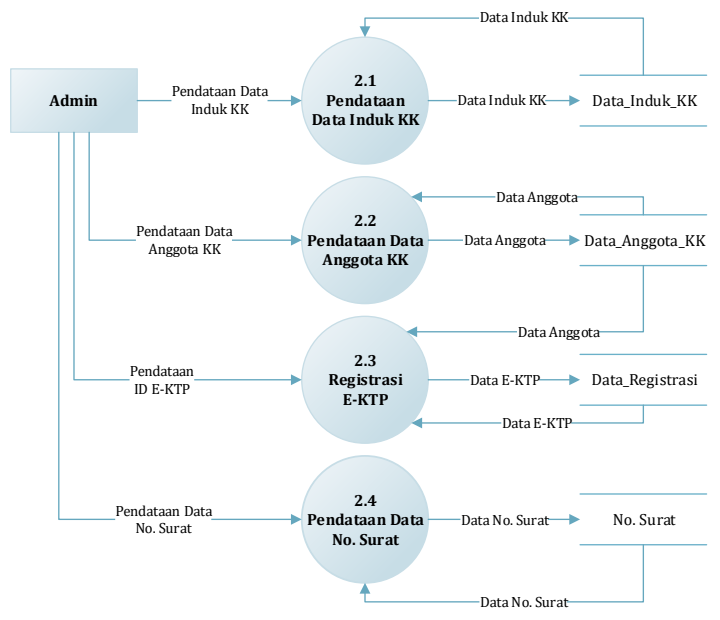

Gambar 5. DFD Level 2 Proses Pendataan

Gambar 5 merupakan DFD Level 2 Proses Pendataan yang dijelaskan dengan lebih rinci. Pada level ini admin bisa melakukan input/simpan data, edit data, dan hapus data. Dari setiap aksi tersebut akan disertai dengan verifikasi data dan setiap aksi yang dijalankan akan mempengaruhi setiap tabel di database.

\section{DFD Level 2 Proses Informasi Data}

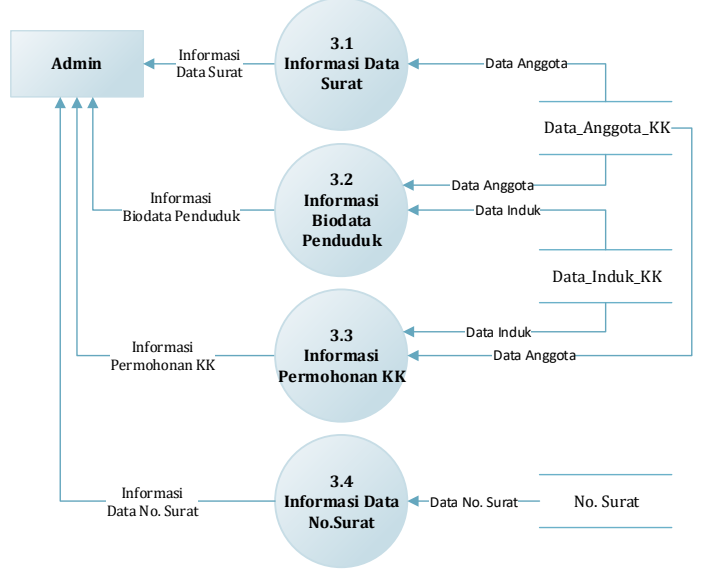

Gambar 6. DFD Level 2 Proses Informasi Data

Gambar 6 merupakan DFD Level 2 Proses Informasi Data yang menjelaskan lebih rinci dari proses informasi data. Pada level ini admin akan mendapatkan informasi yang diperlukan terkait informasi data surat, informasi biodata penduduk, informasi permohonan KK, dan informasi data nomor surat. Untuk mendapatkan informasi tersebut admin perlu memasukkan NIK atau nomor KK sebagai data rujukan sehingga, secara otomatis sistem akan menampilkan informasi sesuai dengan data rujukan.

\section{HASIL DAN PEMBAHASAN}

Pelaksanaan kegiatan pemberdayaan masyarakat terbagi menjadi tiga tahap, yaitu penyadaran, pengkapasitasan dan pemberdayaan/ pelembagaan. Metode pendekatan dalam menyelesaikan masalah yang ada yaitu dengan melakukan Metode Transfer Teknologi (Ipteks) melalui pelatihan, praktek dan pendampingan tentang penggunaan Aplikasi Pelayanan Terpadu sesuai standard dan mengenalkan pada mitra tentang Aplikasi Pelayanan Terpadu yang lebih baik, efisien, dan cepat sehingga proses pelayanan terhadap masyarakat bias lebih efektif dan efisien.

Dampak dari kegiatan Kegiatan Pemberdayaan Masyarakat Politeknik Negeri Ketapang bersama mitra dapat ditelusuri melalui Aplikasi Pelayanan Terpadu yang sudah di Implementasikan di Desa Suka Mulia dalam proses pelayanan masyarakat.

\section{Kegiatan Tahap Penyadaran}

Inti kegiatan tahap penyadaran melakukan persiapan-persiapan sebelum pelaksanaan kegiatan pemberdayaan masyarakat dilaksanakan yang meliputi observasi, studi pendahuluan, perumusan masalah, pengumpulan, analisis data, perancangan sistem, pembuatan sistem, dan koordinasi dengan mitra kemudian dilanjutkan dengan transfer Ipteks yang diimplementasikan dalam bentuk sosialisasi, pelatihan dan demonstrasi. Pelatihan dimulai dengan ceramah untuk menggugah kesadaran dan memberi pengetahuan, dilanjutkan dengan demonstrasi untuk memberi pengetahuan praktis. Kegiatan sosialisasi dan demonstrasi dilaksanakan pada tanggal 11 Agustus 2018 di Aula Kantor Desa Suka Mulia dan dihadiri oleh Kepala Desa Suka Mulia, Perangkat Desa Suka Mulia, Ketua BPD dan LPM Desa Suka Mulia, Ketua RT dan RW Desa Suka Mulia, Masyarakat Desa Suka Mulia, Pendamping Desa Lokal Desa, Kaur 
Pemerintahan dan Kaur Umum SeKecamatan Sungai Melayu Rayak, Kepala P3KM Politeknik Negeri Ketapang, Dosen dan Mahasiswa Politeknik Negeri Ketapang. Tema yang diambil adalah "Pemberdayaan Masyarakat Desa Dalam Meningkatkan Mutu Pelayanan Masyarakat Melalui Aplikasi Pelayanan Terpadu Di Desa Suka Mulia Kecamatan Sungai Melayu Rayak Kabupaten Ketapang Kalimantan Barat”.

Melalui kegiatan sosialisasi Kegiatan Pemberdayaan Masyarakat ini, diharapkan dapat menggugah dan mendorong sikap serta aksi positif yang kontinyu dalam melakukan peningkatan mutu pelayanan masyarakat di Desa Suka Mulia. Kegiatan workshop dimulai secara resmi dengan pemberian kata sambutan dari pihak Mitra, Kepala P3KM dan panitia tim Kegiatan Pemberdayaan Masyarakat, serta penyerahan Alat dan Aplikasi secara simbolis kepada Mitra (Gambar 7).

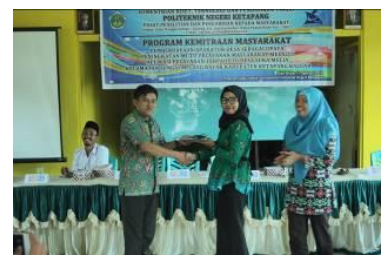

Gambar 7. Penyerahan Alat dan Aplikasi dari Ketua PKM Kepada Mitra

Materi yang diberikan pada kegiatan workshop ini berkenaan dengan penggunaan Aplikasi Pelayanan Terpadu Di Desa Suka Mulia sebagai upaya Peningkatan Mutu Pelayanan Masyarakat. Pada kegiatan P2M ini tidak hanya melibatkan tenaga pendidik Program Studi Teknik Informatika Politeknik Negeri Ketapang, namun turut juga mengikutsertakan mahasiswa Program Studi Teknik Informatika Politeknik Negeri Ketapang. Pemberian materi penggunaan Aplikasi Pelayanan Terpadu disampaikan oleh dosen dan diikuti secara antusias oleh peserta workshop yang dapat dilihat dari diskusi aktif (Gambar 8).
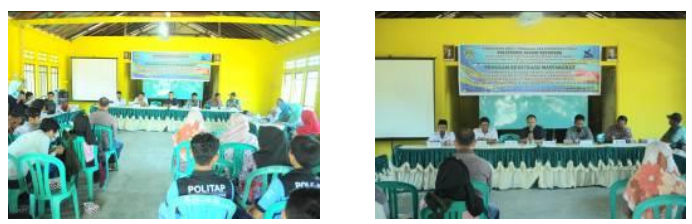
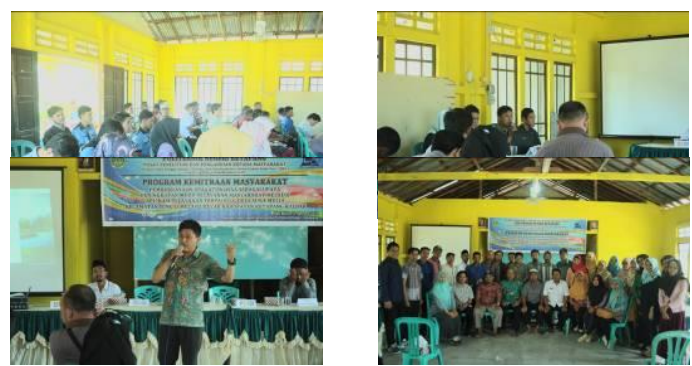

Gambar 8. Pemaparan Materi Aplikasi Pelayanan Terpadu

\section{Kegiatan Tahap Pengkapasitasan}

Inti kegiatan tahap kedua adalah menerapkan ilmu pengetahuan dan teknologi melalui pelatihan (workshop) untuk melatih keterampilan sehingga terjadi pengkapasitasan Ipteks masyarakat. Implementasi dari hasil workshop penggunaan Aplikasi Pelayanan Terpadu di Desa Suka Mulia, dilaksanakan oleh para perangkat Desa Suka Mulia dan dimonitor langsung oleh Tim Kegiatan Pemberdayaan Masyarakat Politeknik Negeri Ketapang.

\section{Kegiatan Tahap Pemberdayaan/ Pelembagaan}

Inti kegiatan tahap ketiga ini adalah monitoring dan evaluasi. Tahap pemantauan dari hasil kegiatan pelatihan serta implementasi penggunaan aplikasi pelayanan terpadu, dimana indikator kerja dapat dilihat sejauh mana masyarakat telah memahami dan mempraktekkan penggunaan aplikasi pelayanan terpadu, melalui interview kepada perangkat desa terkait pelatihan dan implementasi penggunaan aplikasi pelayan terpadu dalam pelayanan terhadap masyarakat.

Selain itu dilakukan evaluasi terhadap aplikasi secara menyeluruh, apakah aplikasi tersebut dapat di implementasikan sesuai dengan kebutuhan masyarakat sehingga aplikasi yang dikembangkan dapat digunakan dengan mudah oleh masyarakat. 


\section{KESIMPULAN}

Kegiatan pengabdian kepada masyarakat melalui Program Kemitraan Masyarakat yang dilakukan antara Program Studi Teknik Informatika Politeknik Negeri Ketapang dan mitra Desa Suka Mulia Kecamatan Sungai Melayu Rayak Kabupaten Ketapang Kalimantan Barat beberapa output dan luaran, yakni :

1. Kegiatan Pemberdayaan Masyarakat Desa dalam Meningkatkan Mutu Pelayanan Masyarakat Melalui Aplikasi Pelayanan Terpadu Di Desa Suka Mulia Kecamatan Sungai Melayu Rayak Kabupaten Ketapang Kalimantan Barat berlangsung lancar dan diikuti oleh Kepala Desa Suka Mulia, Perangkat Desa Suka Mulia, Ketua BPD dan LPM Desa Suka Mulia, Ketua RT dan RW Desa Suka Mulia, Masyarakat Desa Suka Mulia, Pendamping Desa Lokal Desa, Kaur Pemerintahan dan Kaur Umum SeKecamatan Sungai Melayu Rayak, Kepala P3KM Politeknik Negeri Ketapang, Dosen dan Mahasiswa Politeknik Negeri Ketapang. Materi mengenai penggunaan Aplikasi Pelayanan Terpadu Di Desa Suka Mulia sebagai upaya Peningkatan Mutu Pelayanan Masyarakat, disampaikan dengan baik dan direspons dengan antusias oleh peserta workshop.

2. Pelaksanaan kegiatan pemberdayaan masyarakat terbagi menjadi tiga tahap, yaitu persiapan, pelaksanaan/pelatihan, dan monitoring. Metoda pendekatan dalam menyelesaikan masalah yang ada yaitu dengan melakukan Metode Transfer Teknologi (Ipteks) melalui pelatihan, praktek dan pendampingan tentang penggunaan Aplikasi Pelayanan Terpadu sesuai standard dan mengenalkan pada mitra tentang Aplikasi Pelayanan Terpadu yang lebih baik, efisien, dan cepat sehingga proses pelayanan terhadap masyarakat bias lebih efektif dan efisien.

3. Aplikasi yang dibangun berupa aplikasi pelayanan terpadu di Desa Suka Mulia untuk meningkatkan Mutu Pelayanan Masyarakat.

\section{DAFTAR PUSTAKA}

- Anggraeni, E.Y., dan Irviani R. 2017. Pengantar Sistem Informasi. Yogyakarta : CV. Andi.

- Komputer, W. 2010. Shourtcourse Pengembangan Aplikasi Database Berbasis JavaDB dengan Netbeans. Yogyakarta : CV. Andi.

- Muslihudin, M. 2016. Analisis dan Perancangan Sistem Informasi Menggunakan Model Terstruktur dan $U M L$. Yogyakarta : CV. Andi.

- Shelly, Cashman, dan Vermaat. 2007. Discovering Computers Menjelajah Dunia Komputer Edisi 3. Jakarta : Salemba Infotek.

- Sitorus, L. 2015. Algoritma dan Pemrograman. Yogyakarta : CV. Andi.

- Sugiyono. 2016. Metode Penelitian Kuantitatif, Kualitatif, dan $R \& D$. Bandung : Alfabeta. 